\title{
Mezinárodní paralely postavy kinderschrecka $v$ procesu remediace
}

\author{
Marta Pavelková
}

DOI: 10.21104/CL.2020.2.06

International Versions of Kinderschreck in the Remediation Process

\begin{abstract}
This study deals with an overview of international versions of the folk character kinderschreck, a pedagogical bogeyman that scares children. The research probe is based on testimonies of respondents from thirteen countries in Europe and beyond. The work includes characters based on traditional folklore narratives, as well as mentions of characters that are known mainly due to popular culture. It turns out that popular culture is an indispensable factor in the migration of folklore narratives and their subsequent transformations.
\end{abstract}

\section{Key words}

international folklore, popular culture, kinderschreck, remediation

\section{Acknowledgment}

Tato studie vznikla v rámci specifického vysokoškolského výzkumu 260484a/2018 řešeného na Filozofické fakultě Univerzity Karlovy.

\section{Contact}

Mgr. Marta Pavelková, Ústav etnologie, Filozofická fakulta, Univerzita Karlova, Celetná 20,110 00 Praha 1, Czech Republic; e-mail: m.pavelkova0@ seznam.cz

\section{Jak citovat / How to cite}

Pavelková, Marta. (2020). Mezinárodní paralely postavy kinderschrecka v procesu remediace. Českýlid 107, 231-252. doi:http://dx.doi.org/10.21104/ CL.2020.2.06 


\section{Úvod}

V současné etnologii je stále přítomna tendence rozlišování mezi dětským folklorem a folklorem pro děti (Pospíšilová 2005: 116). Součástí dětského folkloru by měly být př́běhy šířené dětmi mezi děti, folklorem pro děti se pak chápe to, co se k dětem dostává prostřednictvím rodičů či jiných dospělých osob. Samotná kultura a folklor dětí pak vychází ze vzorů přebíraných z kultury dospělých. (Bittnerová - Janeček 2011: 13) V současném terénu je však možné vidět, že toto rozdělení již zcela nevyhovuje potřebám moderní folkloristiky, která kromě orálních narativů pracuje mimo jiné i s digitálními médii, jejichž obsah, se kterým se děti setkávají, se př́liš často vymyká vymezeným rámcům obou kategorí́. To lze sledovat i na př́ikladu dětských strašidel neboli kinderschrecků.

Kinderschreck je postavou dobře známou mnoha malým dětem. Jsou to monstra, kterých se děti bojí, když si před spaním nevyčistí zuby, když se přejídají sladkostmi či zkrátka neposlouchají své rodiče. Kinderschreck neboli dětské strašidlo je prastarý disciplinační nástroj užívaný ve výchově. Skrze vyprávění o takovýchto strašidlech se děti mohou lépe socializovat a přizpůsobit prostředí, ve kterém vyrůstají (Bascom 1954: 346). Bylo by však chybou považovat kinderschrecky za bytosti určené pouze k trestání neposlušných ratolestí. V rozšířeném významu jsou totiž i oblíbeným nástrojem šiření strachu mezi dětmi samotnými. Kinderschreck již celá staletí představuje monstrum kombinující prvky sociokulturních norem předávaných rodiči a primárního iracionálního strachu. Podoby i funkce dětských strašidel se mění v závislosti na čase i prostředí. Tato proměna přirozeně zrcadlí změny ve společnosti ovlivněné průmyslovou revolucí, masmédii a př́íchodem Webu 2.0.

Jak již bylo řečeno, kinderschreci nepředstavují novodobý koncept. Pod různými hesly je lze najít i v rozsáhlém folkloristickém katalogu sestaveném folkloristou Stithem Thompsonem Motif-Index of Folk-Literature (Thompson 1989). Dětská strašidla netvoří v Thompsonově katalogu samostatnou explicitní skupinu, nicméně jednotlivá strašidla zde mohou být zastoupena různými více či méně obecnými motivy. Tyto motivy mohou odkazovat na úzce specifické bytosti (např. motiv s číslem B15.6.2. Empúsa $a^{1}$ nebo i skupiny osob, které mohou v různých tradicích fungovat jako kinderschreci (např. motiv E250. Krvežízniví revenanti ${ }^{2}$ či G200. Čarodějnice $^{3}$ ) (Thompson 1989).

\footnotetext{
1 V anglickém znění „Empousa“.

2 V anglickém znění „Bloodthirstyrevenants“.

3 V anglickém znění „Witch“.
} 
Ačkoli si dnes mnoho lidí ze svého dětství nevybaví žádné babiččiny př́iběhy o škrabinožkách, a mají tedy pocit, že se jich dětská strašidla nikdy nijak nedotkla, téměř každý má svou vlastní zkušenost s čerty, Bloody Mary či pouhým nepř́ijemným pocitem, že se něco nebezpečného skrývá pod jeho postelí.

Otázka užívání strachu jakožto disciplinačního prostředku je stále probíraná a aktuální, samotný obsah vyprávění ale bývá odsunován do pozadí. Existuje však mnoho důvodů, proč by nás detaily jako podoba, charakter, projevy či samotné přivolání výchovných strašidel měly zajímat. Tento článek představuje stručný přehled výskytu narací spojených $\mathrm{s}$ dětskými strašidly $\mathrm{v}$ zahraničí. Zmíněné narace jsou následně konfrontovány s literaturou, př́padně i s pozměněnou formou, kterou postupem času získaly vlivem populární kultury. Provedená komparace pak dává vyniknout procesům migrace a evoluce jednotlivých postav a motivů. Práce vychází ze dvou výzkumů prováděných v českém i zahraničním prostředí.

V letech 2016-2017 proběhla první vlna mého výzkumu kinderschrecků, v němž jsem mapovala výskyt dětských strašidel v českém prostředí. Tento výzkum byl realizován $\mathrm{v}$ rámci diplomové práce zaměřené na fenomén antropofágie $\mathrm{v}$ kontextu světového folkloru. Na průzkumu se podílelo celkem osmdesát respondentů napříč věkovými kategoriemi.

Druhý výzkum, tentokrát z roku 2019, byl pak zaměřen na kinderschrecky v zahraničí.

\section{Kdo je vlastně kinderschreck?}

Kinderschreck se často chápe pouze jako bytost, jež je rodiči užívána $\mathrm{k}$ výchově dětí. Používá se jako jakási výhružka pro všechny, kteří neposlouchají rady a př́kazy dospělých. $V$ této práci však považuji za nutné zmíněnou definici značně rozšśritit. $\mathrm{V}$ první řadě je potřeba zdůraznit, že pojem kinderschreck v mé práci funguje jako hyperonymum spojující všechny typy dětských strašidel.

Koncept postavy trestající neposlušné děti nepřináleží pouze moderní době. Existuje mnoho záznamů dokazujících, že užívání strachu k výchově a formování osobnosti potomků bylo běžné už v minulosti. Př́kladem mohou být třeba Aboriginci se svými příběhy o Kara-ma-yha-woho, malých mužících s hlavou měrící čtyři stopy. Na této hlavě mají ohromná ústa, kterými mohou polykat děti bez potřeby kousání (Smith 1930: 342).

Kinderschreci nemusí být vždy bytostmi nadpřirozenými. To dokazuje př́klad takzvaných Bush Indians, kterými se straší děti kmene Ahtna na území dnešní Aljašky (de Laguna - McClellan 1981: 657). Dětským 
strašidlem tedy mohou být i př́slušníci znepřáteleného kmene či nebezpeční vyvrženci, kteř́ jsou však veskrze lidští.

Lidé malajského kmene Dusun věrí, že jejich nejmladší mohou utrpět újmu např́iklad od duší mrtvých stejně jako od nebezpečných zvířat z džungle (Williams 1965: 88). Děti všechny tyto tragické scénáře znají z písní i ukolébavek, nejsou však jedinými, kteří těmto příběhům věří. Běžnou praxí bylo zamykání dětí v samostatných místnostech $\mathrm{v}$ domě, aby se k nim zmínění kinderschreci nemohli dostat, když rodiče odešli pracovat na pole (Williams 1965: 81). Dětská strašidla jsou tedy mnohdy reálná jak pro děti, tak dospělé.

Ačkoli původní účel kinderschrecků spočíval často v prevenci toulání dětí po okolí či neopatrného jednání (hlasitý pláč atd.) v prostředí mimo bezpečí vesnice, výskyt těchto bytostí se z příběhů nevytratil ani postupem času.

$\mathrm{V}$ moderních komplexních společnostech se vyprávění z tématu nebezpečí př́rody přesouvají $\mathrm{k}$ otázkám hygieny, přejídání sladkostmi, ponocování a celkové poslušnosti vůči rodičům (Sugiyama - Sugiyama 2011). Pod vlivem populární kultury, tedy knih, filmů či internetu, kinderschreci mění svou podobu i pole působnosti. Filmové pohádky a filmy všeobecně se staly běžnou náhražkou ústního vyprávění, děti se proto často bojí hraběte Draculy, Freddyho Kruegera nebo náhodného sériového vraha. ${ }^{4}$ Děti se také často straší navzájem bez dohledu rodičů. $\mathrm{K}$ tomuto účelu užívají kinderschrecky, o nichž už dříve slyšely, ale vytvářejí i nové. Ve výpovědích se tedy mohou objevovat tradiční disciplinační strašidla zbavená své výchovné role.

$\mathrm{Z}$ těchto důvodů je přesná definice dětských strašidel přinejmenším nesnadná. Na následujících stránkách pracuji především s materiály, které jsem během několika měsíců aktivně dokumentovala formou dotazníků a polostrukturovaných rozhovorů s respondenty $\mathrm{z}$ mnoha evropských i mimoevropských zemí. Za kinderschrecka zde tedy považuji jakýkoli antropomorfizovaný fenomén, jehož se mí respondenti v dětství dlouhodobě obávali. Zdrojem tohoto strachu pak musel být příběh, který daná osoba slyšela od dospělých autorit, sourozenců či přátel, nebo př́iběh převzatý z popkulturního zdroje (vyprávění na internetu, vyprávění inspirované knihami a filmy).

\section{Metodologie}

Tato práce vznikla na základě výzkumné sondy dotazníků sesbíraných z celkem třinácti zemí (Brazílie, Francie, Indonésie, Itálie, Kolumbie, Me-

\footnotetext{
$4 \quad$ FR, žena, 26 let, Francie.
} 
xiko, Německo, Nizozemsko, Pákistán, Portugalsko, Sýrie, Turecko a Velká Británie). Distribuovaný dotazník ${ }^{5}$ sestával z dvanácti otázek, z čehož pět bylo uzavřených (otázky týkající se osobních údajů respondenta) a sedm otevřených. $V$ př́ípadě, že se v dotazníku objevila pouze povrchní zmínka o kinderschreckovi, která nebyla dále rozvedena, byl tento dotazník doplněn o následný rozhovor o tomto konkrétním strašidlu. V dotazníku se mimo jiné ptám na všechna dětská strašidla, která dotazovaný zná. Zjištuji, jaké aktivity jsou pro zmíněná strašidla charakteristické, tedy jakým způsobem se ve svém okolí projevují. Dále se ptám na osobní zkušenosti s dětskými strašidly. Respondenti zde sdělovali, zda se s podobnými př́běhy setkávali prostřednictvím rodičů, sourozenců, přátel apod., a pokud ano, zda vědí, odkud znalost těchto př́běhů pramení. Poslední dotaz je mířený na samotnou redistribuci zmíněných příběhů, zajímá mě tedy, zda respondent někdy o dětských strašidlech vyprávěl a užíval je ke strašení jiných, at již dětí, či svých soudobých vrstevníků.

Dotazník byl distribuovaný prostřednictvím internetu ${ }^{6}$ a respondenty se $\mathrm{v}$ tomto př́padě stávali pouze dobrovolníci, kteří se chtěli aktivně podílet na mém prvotním výzkumu.

Pro získání dobrovolníků byla užita asociativní metoda. Kromě výše zmíněných států byli osloveni i zástupci mnoha dalších zemí (Švýcarsko, Švédsko, USA, Austrálie, Jihoafrická republika, Polsko, Španělsko, Bulharsko a Rumunsko), od kterých prozatím nejsou žádné výsledky dostupné.

Ve fázi distribuce jednotlivých dotazníků byli nejprve osloveni mí známí. Ti pak dotazníky šírili dál.

Z počtu více než padesáti dobrovolníků byl dotazník vyplněn osmadvaceti respondenty. ${ }^{7}$ Největší návratnost vykázaly dotazníky šířené v Brazílii (celkem pět kompletně vyplněných dotazníků). Z Portugalska byly získány odpovědi od čtyř osob, z Itálie a Německa od tř́i. Dva vyplněné dotazníky přišly z Mexika, Francie, Velké Británie a Turecka a po jednom z Pákistánu, Indonésie, Sýrie, Kolumbie a Nizozemska. Komunikačním jazykem prováděného sondážního výzkumu byla angličtina.

Věk respondentů se pohybuje v rozmezí od jedenadvaceti do třiačtyřiceti let. Data získaná od této věkové kategorie přináší retrospektivní rekonstrukci vyprávění o dětských strašidlech, zároveň nastiňují současné př́ístupy k takovýmto naracím, jelikož mnoho dotazovaných má již vlastní děti.

5 Vzor dotazníku byl převzat $\mathrm{z}$ mého výzkumu kinderschrecků v českém prostředí (2016-2017).

6 Konkrétně se jednalo o e-mailové komunikace, zprávy zasílané skrze elektronické sociální sítě a doplňkové rozhovory uskutečněné přes videochat.

7 Někteři přihlášení dobrovolníci své odpovědi stále neposkytli. 
Provedená výzkumná sonda nemá ambice kompletně analyzovat mezinárodní výskyt kinderschrecků, jejich historických pravzorů či transformací. Práce, kterou zde prezentuji, je pouze prvním krokem směřujícím $\mathrm{k}$ budoucímu detailnímu zkoumání dané problematiky. Cílem studie je především poukázat na současnou proměnu tradičních vyprávění o dětských strašidlech. Zároveň se zde zamýšlím nad podobnostmi mezi kinderschrecky v různých kulturách. Tyto společné rysy různých monster pak mohou tvořit základy postav a strašidel, která známe z populární kultury.

\section{Bubák}

Nejčastěji zmiňovaným strašidlem bylo během mého sběru nepochybně monstrum, jež by se $\mathrm{v}$ českém prostředí dalo připodobnit $\mathrm{k}$ tradičnímu bubákovi. ${ }^{8}$ Bubák, ${ }^{9}$ tak jak byl respondenty popsán, se často schovává v temných zákoutích dětského pokoje. Číhá pod postelí, krčí se v šatní skř́ni či jen tak postává v tmavém rohu. Fyzická podoba bubáka je nejasná, často se jedná o strašidlo neustále měnící svůj fyzický vzhled tak, jak se mu za daných okolností nejvíce hodí. To mu v některých př́padech pomáhá zůstat nenápadným, když se blíží starostliví rodiče. Konkrétní projevy bubáka jsou velice individuální záležitostí.

V Brazílii se mu ř́ká Bicho-papão (složenina slov „bicho“ a „papar“, tedy „netvor" a „jíst" či „požírat") a je velice známým lidojedem - jak již vyplývá z jeho jména, brazilský bubák pojídá neposlušné děti. Mnohdy má také moc nad nočními můrami, které může na neposlušné dítko seslat. Mezi jeho výstražné projevy patří všemožné šramocení a skř́ípání - tedy neidentifikovatelné strašidelné zvuky, kvůli kterým nemůžou děti hrůzou usnout. ${ }^{10}$ Bicho-papão je strašidlo, jehož existence je základem narativů napřič celou zemí a všemi věkovými kategoriemi. Všichni brazilští respondenti uvedli, že tyto př́běhy znají od rodičů či prarodičů, kteří je zase slyšeli od svých předků. $\mathrm{Z}$ odpovědí respondentů prozatím usuzuji, že Bicho-papão bývá úzce propojen s výchovou. Na rozdíl od českého bubáka totiž straší a požírá pouze neposlušné děti. ${ }^{11}$

Z výzkumu prováděného v letech 2016-2017 vyplývá, že v českém prostředí je prostor pod postelí rovněž místem vzbuzujícím obavy. Děti často pocitují intuitivní strach, jelikož tmavé kouty a prázdné prostory v nich vyvolávají nedůvěru a pocit, že se v nich něco skrývá. Toto často blíže nespecifikované „něco“ pak může být nazýváno bubákem (díky vysoké pro-

\footnotetext{
8 Zmíněno dvaceti respondenty z celkového počtu osmadvaceti.

9 Během výzkumu jsem pro termín „bubák“ používala anglický překlad „boogeyman“.

10 Dotazníky č. 1-5, Brazílie.

11 Dotazníky č. 1-5, Brazílie.
} 
měnlivosti projevů i fyzické podoby je totiž každá definice odpovídající). Tento strach může být posílen přičiněním starších sourozencủ, kamarádů a televizních filmů. Český bubák má tedy málo co dočinění s dětskou disciplínou. Ze sedmadvaceti respondentů zmiňujících bubáka ve svých odpovědích pouze tři vypověděli, že toto strašidlo znají od rodičů.

Český bubák má nicméně i mnoho lokálních variant. Jedním z nich je např́íklad Kumraus, jehož výskyt v podkrkonošském městečku Pecka zdokumentoval český folklorista Pavel Kracík. Peckovský Kumraus představuje stejně jako jeho mezinárodní paralely varovnou bytost, přichází tedy za jasně daných podmínek. $\mathrm{V}$ tomto konkrétním př́padě jsou podmínkami soumrak či pouhá potřeba rodičů postrašit děti v jakoukoli denní či noční hodinu (Kracík 2018: 87).

Francouzský bubák se jmenuje Croque-mitaine a stejně jako jeho mezinárodní paralely také on se schovává nejčastěji pod dětskou postelí. Jeho výskyt je opět spojován s neposlušností. Trestány jsou především děti, které před spaním snědly př́liš mnoho sladkého, nevyčistily si zuby nebo prostě jen během dne odmlouvaly rodičům. ${ }^{12}$ Croque-mitaine své oběti stahuje pod postel za chodidla, největším lákadlem jsou pro něj nepřikrytá chodidla zlobivých dětí. Francouzští respondenti uvádějí, že př́běhy o něm znají z vyprávění svých rodičů a prarodičůu, jedná se tedy opět o dlouhodobou hluboce zakořeněnou tradici. ${ }^{13}$

Během výzkumu se často stávalo, že dotazovaní neznali specifické jméno pro bubáka, popis jeho chování byl však vždy stejný: fyzicky blíže nespecifikované monstrum schovávající se pod postelí či v šatní skříni, které v noci unáší nebo žere neposlušné děti.

Se zajímavým prvkem přichází německý Butzemann. K jinde často vágnímu konceptu unášení dětí přidává ikonický nástroj, pytel. Muž či př́šsera s velkým pytlem na zádech děsí děti po celém světě stejně jako bubák pod postelí. Tyto dvě postavy také často splývají v jednu.

V Brazílii a Portugalsku je známý Homem do Saco (také Velho do Saco, ve Španělsku El Hombre del Saco) neboli muž s pytlem. Tento tajemný muž v sobě spojuje prvky nadpřirozeného bubáka s obyčejným nebezpečným člověkem. Nejčastěji je však mými respondenty popisován jako starý muž unášející děti. ${ }^{14}$ Ohroženy jsou zpravidla děti, které se toulají mimo domov po setmění, chodí na místa, kam jim rodiče zakázali vstup atp.

V Kolumbii, Brazílii, Mexiku a Portugalsku je nejznámějším strašidlem Cucuy (jinak také Cuca, Cuco). Brazilská Cuca je čarodějnice často při-

12 RB, muž, 23 let, Francie; FR, žena, 26 let, Francie.

13 RB, muž, 23 let, Francie; FR, žena, 26 let, Francie.

14 Dotazníky č. 1-5, Brazílie, dotazník č. 10, Itálie, dotazník č. 12, Kolumbie, dotazník č. 13, Mexiko, dotazníky č. 14-16, Německo, dotazník č. 26, Turecko. 
podobňovaná ke krokodýlovi. Když dítě hlasitě pláče nebo nechce spát, odnese si ho. Pro tyto účely s sebou nosí velký pytel, do kterého se vejde každé dítě. Brazilské děti znají prúběhy o zlé čarodějnici od svých rodičů a prarodičů. Nejběžněji se vyskytuje v ukolébavkách. Postava Cucy je prý založená na její portugalské verzi, v níž má podobu draka. ${ }^{15}$

V Kolumbii se setkáme se strašidlem zvaným El Coco. Způsoby, jakými El Coco trestá neposlušné děti, jsou rozličné. Základ tvoří vždy únos $\mathrm{v}$ pytli, který si strašidlo nosí přehozený přes rameno. $\mathrm{S}$ unesenými dětmi pak může nakládat různě. Někteří respondenti tvrdí, že jsou děti vystavené neustálému krutému mučení, někteří tvrdí, že se El Coco dětmi živí. Známé jsou i verze př́běhů, v nichž jsou unesené děti prodány. Extrémnější verze těchto příběhů pak tvrdí, že strašidlo vaří z dětí polévku, kterou pak prodává rodičům obětí. ${ }^{16}$

V Mexiku se můžeme setkat s postavou zvanou Cucuy. Tato strašidla se opět specializují na únos zlobivých dětí. V některých př́padech může $\mathrm{Cu}$ cuy fungovat i jako entita neustále sledující děti a jejich chování. Usedává na vrcholky stř̌ech a stromů v podobě stínu, často si své místo hledá i pod postelí nebo ve skříních. ${ }^{17}$

Rakousko a Německo každý večer oživá historkami o již zmíněném Butzemannovi. Jedná se o postavu, jež by se dala popsat jako hraniční charakter mezi bubákem a čertem (jemuž se budu blíže věnovat později). Butzemann je rohatý, s černou pletí či srstí. Schovává se zlobivým dětem pod postelí či ve skř́ni a unáší je do lesa ve velkém pytli. Takový osud potká všechny děti, které zůstaly vzhůru i po večerce..$^{18}$

Bubák, El Coco - at' už se mu ř́ká jakkoli, jedná se o bytost dobře známou téměř všem kulturám po celém světě. Není tedy žádný div, že jeho odraz je patrný také $\mathrm{v}$ populární kultuře. Jak již bylo výše zmíněno, ze sondážního výzkumu prováděného v letech 2016-2017 vyplývá, že především české děti považují bubáka za strašidlo ohrožující své okolí bez ohledu na neposlušnost. Př́běhy o něm tedy neznají od svých rodičů, ale hlavně z televize. Faktem je, že postava komodifikovaného boogeymana je v kinematografii obecně poměrně oblíbená. Kromě očividného hororového žánru jsou bubáci ústředním tématem mnoha komediálních seriálů či seriálů pro mládež. Mezi takové patří např́iklad americký dětský seriál Wizards of Waverly Place (2007), kde se objevují jak duchové strašící malé děti, tak i Cucuy, jímž rodiče strašili jednu z protagonistek, jejíž posta-

15 PHSM, muž, 29 let, hudebník, Brazílie.

16 DO, muž, 35 let, elektrikář, Kolumbie.

17 Dotazníky č. 1-5, Brazílie, dotazník č. 12, Kolumbie, dotazník č. 13, Mexiko, dotazníky 20-23, Portugalsko.

$18 \mathrm{CN}$, muž, 26 let, učitel, Německo. 
va má mexické kořeny. Jednu epizodu věnuje bubákovi i seriál Buffy the Vampire Slayer (1997). ${ }^{19}$ Boogeyman nebyl opomenut ani ve snímku The Nightmare Before Christmas (1993). Postava inspirovaná klasickým boogeymanem, Oogie Boogie, je zároveň jediným záporným charakterem filmu. Oogie Boogie svou inspiraci v dětském folkloru vskutku nezapře. Jeho zevnějšek na první pohled nápadně připomíná velký pytel, jenž je naplněn tisícem brouků. Sám o své postavě rovněž referuje jako o „stínu“. Oogie Boogie je bytostí šiŕící strach, kamkoli vkročí.

Respondenti z Mexika se ve svých vyprávěních někdy odvracejí od klasických ukolébavek o Cucuyovi a nahrazují je strašidelnými historkami založenými především na vyobrazení Cucuye v populární kultuře. To jen dokazuje, že ačkoli je ústní tradice spojená s kinderschrecky stále živá a důležitá, nelze ji dále nahlížet samostatně, nebot' je zpětně ovlivněna jinými médii. Snímek Cucuy: The Boogeyman z roku 2018 např́íklad prezentuje mexické strašidlo jako netvora s pytlem, jenž pro unesené děti představuje bránu do jiného, mystického světa. Zde jsou děti Cucuyem vězněny a ve velkém počtu pomalu umírají. Zajímavý, nicméně velice ojedinělý popis Cucuye nabízí americký televizní seriál Grimm (2011), ${ }^{20}$ v němž je strašidlu připisována veskrze pozitivní role mstitele vraždící trýznitele žen. $\mathrm{V}$ tomto př́padě na sebe strašidlo bere podobu stařenky.

\section{Čert}

$\mathrm{V}$ českém prostředí patří čert $\mathrm{k}$ nepochybně nejužívanějším kinderschreckům. ${ }^{21}$ Oblibě se těší především díky jeho bezprostřední fyzické prítomnosti vždy pátého prosince, kdy děti navštěvuje společně se svatým Mikulášem a andělem. Čeští čerti obcházejí domácnosti s pytlem hozeným přes rameno. Zlobivým dětem dávají uhlí či brambory a hrozí, že je odnesou do pekla. V českém prostředí existují doklady o syntéze postav bubáka a čerta datované až do 18. století. Už František Jan Tomsa ve své publikaci z roku 1794 popisuje hrozivou postavu Mikulášova společníka s pytlem přes rameno a řinčící masivními řetězy. Ačkoli je popis shodný s popisem dnešních čertů, Tomsa užívá pouze termín „bubák“ (Tomsa 1794: 49). Charakteristiky čerta má bubák i v dětské básničce Bubák zveřejněné Karlem Jaromírem Erbenem v díle Prostonárodní české písně a ř́kadla z roku 1864:

19 S02E18.

20 S03E05.

21 Ze zmíněného výzkumu vyplynulo, že celých sedmdesát pět procent ze všech osmdesáti dotazovaných bylo někdy strašeno čertem či používá čerta ke strašení jiných. 


\section{„Sedí bubák pod komínem \\ a má duš̌ rohatou, nese v ní homolky skmínem, hlavu celou chlupatou: mlč a neplač, mé dítè - prïjde homolka a sni tè! $!^{(22}$}

V minulosti měl tedy český bubák více společných rysů např́klad s německým Butzemannem. Z mého výzkumu dětských strašidel v České republice realizovaného v letech 2016-2017 však toto spojení již zřejmé není. Z celkového počtu osmdesáti dotazovaných byl čert zmíněn šedesátkrát. Bubák byl respondenty zmíněn v sedmadvaceti př́padech, ani jednou však jeho popis nepřipomínal moderního čerta.

Z rozhovorů vedených s obyvateli Rakouska a Německa je jasné, že postava čerta (respektive postava čertovi velice podobná) není pouze českou záležitostí. V Německu je známým kinderschreckem např́íklad Knecht Ruprecht, jenž je rovněž společníkem svatého Mikuláše. ${ }^{23}$ Na rozdíl od českého čerta však disponuje dřevěnou holí, kterou neposlušné a zlobivé děti bije. Některé zdroje uvádějí, že své rány rozdává rovněž pytlem, ve kterém nosí popel (Thorpe 1852: 146). Nezbedníci se i od něj mohou dočkat únosu do pekla, kde mohou být následně snědeni. ${ }^{24}$ Tato bytost, jež je dnes chápána veskrze negativně, ${ }^{25}$ má mnohdy na starost i odměňování dětí poslušných a hodných. Mezi nejběžnějšś odměny patří jablka, perníčky a ořechy. Př́chod Knechta Ruprechta ohlašuje řinčení malých zvonečků zavěšených na jeho ošacení (Thorpe 1852: 146).

Strašidlo s podobnými charakteristikami se ukrývá rovněž pod jménem Krampus (Ridenour 2016). Tito rohatí démoni mívají povětšinou strašidelnějšś vzezření než čeští čerti. Ačkoli je jejich výskyt také spojován s Mikulášem, běžně se objevují i samostatně nebo v rozsáhlých průvodech. Obliba takových průvodů v posledních letech vzrostla, kromě klasických Krampuslauf ted' můžeme děsivé démony s kozími rohy a kopyty potkat i na území České republiky a dalších zemí.

Kromě Krampuse můžeme narazit také na strašidlo zvané perchta. Perchta má své kořeny zřejmě v germánské mytologii (Ridenour 2016). Údajně se jednalo o bohyni dohlížející na ženské práce, jako je např́íklad předení. Bývá také často ztotožňována s Paní Holdou (Ridenour 2016). Perchta se zjevuje v období kolem Vánoc, tradičně obchází domovy s velkým

22 (Erben 2011: 24).

$23 \mathrm{CN}$, muž, 26 let, učitel, Německo.

$24 \mathrm{CN}$, muž, 26 let, učitel, Německo.

25 Viz dotazníky z Německa a Rakouska. 
nožem, kterým trestá nedodržení půstu. Někteří respondenti z Německa rovněž uvedli, že ve svém dětství slýchali př́běhy o tom, že pokud nebudou hodní během celého roku, perchta to pozná a potrestá je rovněž. ${ }^{26}$ Perchty mohou být obecně rozděleny do dvou kategorií: Schönperchten a Schiachperchten. První zmíněnou kategorii tvoří krásné a hodné perchty, druhou naopak ty zlé a ošklivé (ibid.). Ačkoli je kategorie hodných percht nepochybně zajímavá, pro účely této práce se zaměříme pouze na perchty, kterých je nutno se obávat. Ty se v první řadě vyznačují nehezkým vzezřením. Může se jednat o malé stařenky s dlouhým hákovitým nosem, rozcuchanými vlasy a potrhaným oblečením, stejně jako o děsivá monstra s dlouhými tesáky oblečená do králičích kožešin. Výjimkou není ani dlouhý kravský nebo koňský ocas, kopyta, rohy apod. (ibid.). V současnosti je perchta chápána jako bezpohlavní bytost (kořeny charakteru jsou ženské, masku perchty však oblékají především muži a maska sama o sobě bývá natolik zoomorfní, že se veškeré maskulinní či femininní znaky zcela vytrácejí) odměňující hodné a trestající zlobivé děti. ${ }^{27}$

Obraz čerta (respektive př́ibuzných postav Krampuse, perchty atd.) je zvláště v kinematografii velice rozmanitý. Pokud mluvíme o čertovi v českém prostředí, setkáme se nejčastěji s žánrem dětských pohádek, kde jsou čerti často zobrazováni jako strašidelní, nicméně spravedliví strážci spravedlnosti (např. filmová pohádka $S$ čerty nejsou žerty, 1985). Strašidelný charakter postavy čerta pak čas od času ustupuje komediálním prvkům, které poukazují na jakousi lidskou stránku pekelných služebníků. Disponují lidskými slabostmi, jako je lenost, hloupost, soucit apod. (např. Dalskabáty, hř́šñá ves aneb Zapomenutý čert, 1976). V České republice děti vědí, že čert je nebezpečný pouze pro ty, kteří během roku zlobili. Celých devadesát procent respondentů uvedlo, že se čertů báli i v př́ípadě, že přesně věděli, kdo se v čertovském kostýmu ukrývá. ${ }^{28}$ To evokuje hypotézu, že se v tomto př́padě dětský strach nezakládá na samotném narativu o čertech, ale na děsivém zpracování jejich fyzické podoby.

Tento strach pak reflektuje žánr, který si charakter démonického trýznitele dětí zvláště v posledních několika letech velice oblíbil. Jedná se o žánr hororových filmů, pro ty je atraktivní především Krampus. ${ }^{29}$

26 CN, muž, 26 let, učitel, Německo.

27 Předpoklad se zakládá na výpovědích pěti dotazovaných respondentů z Německa.

28 Založeno na mém výzkumu dětských strašidel 2016-2017.

29 Hlubší konfrontace líčení respondentů s literaturou v tomto př́padě bohužel není možná. Respondenti zmiňující Krampuse se omezili pouze na jednoslovné či velmi vágní popisy. 


\section{La Llorona}

Jedním z nejrozšířenějších femininních strašidel je La Llorona, známá také jako plačící žena. Známá je především v oblasti Latinské Ameriky, postavu s podobnými charakteristikami však najdeme i v mnoha dalších kulturách.

Nejtradovanějším příběhem o plačící ženě je ten, podle kterého byla La Llorona krásná dívka žijící v době kolonialismu v Mexiku. Zamilovala se do bohatého Španěla a měla s ním několik dětí (přesný počet se liší v závislosti na zdroji) (Plascencia 2017). Španělský prominent však odmítl učinit jejich vztah oficiálním a místo mladé Mexičanky se oženil se španělskou šlechtičnou. Neštastná La Llorona (respondenti uvádějí, že její pravé jméno je Maria) ze svého zármutku přišla o rozum a v záchvatu šílenství utopila své děti v řece. Když si uvědomila hrůzu činu, který spáchala, vzala život i sobě. Od těch dob se plačící žena zjevuje v okolí řek či jezer, hlasitě naříká a hledá své mrtvé děti (ibid.: 69). Jiné varianty př́iběhu ř́kají, že se Maria za bohatého muže provdala, on ji ale opustil kvưli mladší ženě. Jádro př́iběhu je však vždy stejné: žena ze vzteku a zoufalství zavraždila své děti a poté spáchala sebevraždu. ${ }^{30}$

Př́iběhy o postavě La Llorony se často vypráví dětem, aby se pozdě večer nikde netoulaly. Původní údajný výskyt plačící ženy byl pouze v okolí vody, postupem času se však př́iběhy změnily a rozšírily její pole působnosti i na lesy, či dokonce urbánní prostory (Plascencia 2017: 69). Mnohdy se také užívá jako výhružka určená zvláště chlapcům. Příběhy o překrásné, avšak nebezpečné ženě mají za úkol varovat před př́lišným chtíčem a nevěrou. La Llorona je ve své smrti stejně okouzlující jako během života. Zjevuje se především nevěrným mužům a opilcům, svádí je a poté zavraždí. Když ji vidíte v dálce, má podobu nádherné svůdné ženy, když se k vám však přiblíží, uvidíte ošklivý koňský obličej. V ten moment je již pozdě na útěk (ibid.).

Některé př́iběhy tvrdí, že pokud zaslechnete silný a pronikavý pláč La Llorony, znamená to, že se nachází daleko od vás, pokud ale slyšíte její hlas z dáli, je ve vaší těsné blízkosti (Plascencia 2017: 69).

La Llorona má podle některých interpretací potenciálně částečný základ v postavě z mexické historie. Její jméno bylo Doña Marina (také známá jako La Malinche). Marina byla tlumočnicí a rádkyní španělského conquistadora Hernána Cortése, zároveň byla i matkou jeho syna Martína (Cypess 1991: 7). Marina dnes pro mnoho obyvatel Latinské Ameriky představuje symbol svůdné sexuality a zrady.

Jak již bylo řečeno, bytosti s podobnými charakteristikami, jako má mexická plačící žena, existují v mnoha kulturách. Yucatán má své strašidlo

30 DAMC, žena, 21 let, Mexiko. 
zvané Xtabay, v Kostarice je to La Cegua, El Salvador má zase La Siguana$b u$. Výše zmíněné jsou v některých ohledech velice podobné La Lloroně, v mnohém se ale i liší. La Siguanaba s plačící ženou např́klad sdílí koňskou tvář viditelnou pouze na krátkou vzdálenost, Xtabay zase svádí své oběti, aby je mohla následně usmrtit (Plascencia 2017: 72).

Ve slovanské mytologii lze také najít bytosti ne nepodobné mexickému strašidlu. Mezi takové bytosti patř́ např́klad ruské a ukrajinské rusalky. Nejenže se vyskytují nejčastěji kolem vodních ploch a lákají kolemjdoucí svým půvabným tancem, představují ale často také duše žen, jež spáchaly sebevraždu (Váňa 1990: 111).

Motiv vraždění a unášení dětí s La Lloronou sdílí např́íklad antická $L a$ mia, napůl žena, napůl had. Ta se podle řecké mytologie po nocích plíží po okolí, aby vraždila děti (často děti potulující se venku bez dozoru) a sála jejich krev. Tak činí v aktu pomsty za své vlastní děti zavražděné bohyní Herou (v některých verzích mýtu Hera sešle na Lamiu šílenství, ve kterém své děti zabije ona sama). Lamia je stejně jako La Llorona známou pokušitelkou se schopností měnit svou podobu (Empousa - Lamia 2000).

Jistou podobnost lze vypozorovat i mezi plačící ženou a irskou Bánší. $\mathrm{V}$ tomto př́padě obě bytosti charakterizuje usedavý pláč a nářek. ${ }^{31}$

O mnoho více společných znaků má s La Lloronou postava zvaná Churail. Ta pochází z Pákistánu. Churail je známým kinderschreckem, a to nejen právě v Pákistánu, ale také Indii, Bangladéši (Chawla 1994: 15). Stejně jako La Llorona, Lamia nebo Xtabay i Churail zaměřuje svou zlost především na muže. Ti jsou následně svedeni a zavražděni. Na rozdíl od svých kolegyň však pákistánská svůdnice nedisponuje přirozenou krásou. Má svraštělou kůži, povislá prsa a vlasy připomínající pubické ochlupení. Svou podobu však dokáže libovolně měnit. Jediné, co vždy zůstává, jsou chodidla otočená dozadu. Děti slýchají prř́běhy o této nebezpečné ženě, aby se vyvarovaly nočního toulání. ${ }^{32}$

Nehezkým vzhledem se vyznačuje i poslední z mnou zdokumentovaných paralel La Llorony. Její jméno je Wewe Gombel a pole působnosti má především v Indonésii. Wewe Gombel má podobu staré ženy s velice dlouhými povislými prsy. Legenda praví, že to kdysi bývala žena, kterou opustil manžel. Když ho nachytala při nevěře, zavraždila ho a poté i sebe. Ted' chodí světem a odnáší do svého hnízda děti, o které nebylo dobře postaráno, které jsou zanedbané či neštastné. O unesené děti se prý vždy dobře a láskyplně stará a někdy, pokud se rodiče neštastníků napraví, je do původní rodiny i vrací. Př́běhy o této vcelku mírumilovné postavě se

31 DY, žena, 33 let, skladnice, Velká Británie.

32 UT, muž, 26 let, student, Pákistán. 
vyprávějí opět jako prevence před touláním. Zároveň učí děti nestěžovat si na své rodiče, dodržovat řádnou hygienu, pravidelně jíst zeleninu apod. ${ }^{33}$

Př́běhy o La Lloroně jsou natolik známé, že se staly námětem mnoha filmů či seriálových epizod. ${ }^{34}$

\section{Bloody Mary}

Jádro tohoto strašidelného př́iběhu zpravidla tvoří několik specifických situací. Temná místnost, pohled do zrcadla, vyslovení jména či formule a trest. Existuje nepřeberné množství různých variant př́běhů o Bloody Mary a jejím vyvolání. Některé příběhy vypráví o původu Bloody Mary a jejím osudu, některé jen detailně popisují, co člověk musí udělat, aby se zjevila, a jaké jsou následky jejího úspěšného přivolání.

O původu Bloody Mary můžeme najít téměř tolik příběhů, jako je úst, jež je vyprávějí. Objevují se v nich odkazy na královnu Marii Tudorovnu, Mář́ Magdalenu, Pannu Marii či obyčejnou chudou dívku, která se provinila krádeží. Ačkoli je samotná pověst o Bloody Mary poměrně mladá (v USA byla zaznamenána teprve v sedmdesátých letech 20. století) (Janeček 2015: 106), obsahuje prvky spojující ji s klasickými kinderschrecky již hluboce zakořeněnými v tradičním folkloru.

Př́běhy o tom, kdo byla Bloody Mary, než se stala démonickou bytostí, mají vždy společného jmenovatele, jímž je porušení určitého tabu. Jeden z respondentů ŕíká, že poprvé o Bloody Mary slyšel jako o děvčátku, které ukradlo "chléb nebo něco takového, protože její rodina hladověla“. ${ }^{35}$ Dívka byla chycena při činu a upálena. Neštastná matka se prý za dcerou vrhla do plamenů, ale zachránit ji nedokázala. Nicméně Mary předala natolik své životní energie, že se její duch stihl dostat do malého zrcátka, které měla holčička u sebe. Od té doby se zjevuje v zrcadlech a hledá svou matku. Pokud ji však vyvolá kdokoli jiný, Mary mu ublíží. ${ }^{36}$

Další z př́iběhů popisuje Mary jako ženu, jež byla lidmi považována za čarodějnici. Mary přestala i se svými dětmi vycházet $\mathrm{z}$ domu a v zoufalství je zavraždila. Když se její manžel vrátil z války, svou zuboženou ženu však nepoznal a zabil ji. Když si uvědomil svůj omyl, spáchal sebevraždu. Od té doby se Mary zjevuje každému, kdo třikrát za sebou vysloví „Krvavá Mary“. Daného člověka pak ubodá, toto označení jí totiž připomíná ostrakizaci ze strany krajanů (Janeček 2015: 106). Př́iběh obsahuje hned dva prv-

33 GT, muž, 26, fotograf, Indonésie.

34 Např. snímek The Curseof La Llorona z roku 2019, seriál Grimm (S02E09).

35 Originál: „... bread or something like that cause her family was starving.“ AY, žena, 38 let, Brazílie.

$36 \mathrm{AY}$, žena, 38 let, Brazílie. 
ky, které je nutné zdůraznit. Jde zde samožrejmě o vraždu vlastních dětí, která odkazuje na pověsti o La Lloroně či Lamii, je ovšem třeba věnovat pozornost i druhému prvku, v pověstech o Bloody Mary asi nejběžnějšímu - prvku porušení tabu na vyslovení jména. Respektive vyslovení a následné opakování jména. To se objevuje téměř ve všech verzích. Někdy je potřeba jméno zopakovat třikrát, jindy pětkrát, či dokonce stokrát. A není to vždy jen jméno, mezi formulemi se kromě „Bloody Mary“ objevuje např́klad „Mary Worthington“, „Hell Mary“, „I believe in Bloody Marry“, „Bloody Mary, I got your baby" nebo i odříkání modliteb pozpátku. Formule obsahující zmínku o dítěti opět spojuje Krvavou Mary s La Lloronou.

Respondenti z Brazílie v rozhovorech několikrát ${ }^{37}$ zmínili tradiční strašidlo Comadre florzinha. Jedná se o ženskou postavu, jejíž jméno by bylo možné přeložit jako „Kmotra květinka“. Představuje patronku lesů a př́rody obecně. Zjevuje se v zalesněných oblastech těm, kteř́ se ztratili nebo jsou sami. Pokud dotyčný vysloví její jméno třikrát, začnou se ozývat tiché vzlyky, pískání a další podivné zvuky, jejichž zdroj není možné vysledovat. Když se Comadre florzinha ukáže, bývá krutá a nelítostná. Vlastní bič tvořený kopřivami, jímž trýzní toho, kdo ji přivolal. ${ }^{38}$

Další brazilskou neštastnicí nápadně podobnou Bloody Mary je Loira do Banheiro (lze přeložit jako „Blondýnka z koupelny“). Pověst praví, že se jednalo o mladou dívku, jejíž rodiče se rozhodli domluvit jí sňatek. Ona se však vzbouřila a za peníze získané prodejem rodinných šperků utekla do zahraničí. Nastávající manžel ji však našel a ve vzteku zavraždil v koupelně před zrcadlem. Její tělo bylo převezeno zpět do Brazílie, zpopelněno a uloženo do skleněné urny. Lidem nacházejícím se v okolí této urny se však začaly zdát děsivé sny, které přestaly, až když byla urna pohřbena. Na místě domu dívčiny rodiny se po letech postavila škola, ve které se začaly dít podivné věci. $\mathrm{V}$ zrcadle na dívčích záchodech se dodnes zjevuje slepá dívka $v$ bílých šatech potřísněných krví. Některé verze tvrdí, že je nutné její jméno třikrát před zrcadlem vyslovit, jiné, že se zjevuje sama. At tak či tak, kdo mrtvou dívku v zrcadle spatř́í, postupně přijde o rozum. Toto š́lenství končí až sebevraždou. ${ }^{39}$

V mnoha historkách o Bloody Mary není rovněž vyslovení jejího jména podmínkou. Často se zjevuje sama od sebe, pokud projdeme kolem zrcadla v temné místnosti. Někdy je podmínkou jejího zjevení i určitý den v týdnu (nejčastěji pátek). Vyslovení a opakování jména či formule opět nemusí stačit. Rituál může provázet zapálení svíček, stř́íkání vody na zrcadlo apod. (Norder 1999; 2003)

37 Celkem čtyřikrát ze šesti dotazovaných.

38 YVSS, muž, 26 let, překladatel, Brazílie.

39 YVSS, muž, 26 let, překladatel, Brazílie. 
Stejně jako brazilská Loira do Banheiro i Bloody Mary se projevuje různě. Nejčastěji se lidem zjevuje s nožem v ruce, kterým na člověka zaútočí, lidi však napadá i dlouhými drápy, zuby či nůžkami. Zaměřuje se především na oči, které s oblibou vyškrabává, může člověku ale i uříznout hlavu, pozrít ho, vystrašit $\mathrm{k}$ smrti, zatáhnout $\mathrm{k}$ sobě do zrcadla či, jako $\mathrm{v}$ brazilské pověsti, přivést $\mathrm{k}$ šllenství a donutit spáchat sebevraždu (Norder 1999; 2003).

Vlastní, tradičnější verzi Bloody Mary lze také najít v Mexiku. Zde se často vypráví o dívce Marii zjevující se v podobě napůl holčičky, napůl kostry. Tato tradice je spojena především se svátkem Día de los Muertos, jehož neoficiálním symbolem je lebka či kostra. ${ }^{40}$

Ne všechny projevy Bloody Mary jsou vyloženě negativní. Některé př́běhy ř́íkají, že Mary bude tomu, kdo ji vyvolal, odpovídat na otázky nebo mu vyjeví budoucnost. Existují i verze narace, ve kterých Bloody Mary obdarovává účastníky rituálu hračkami a sladkostmi (Norder 1999; 2003).

Existence př́běhů o Krvavé Mary je neodmyslitelně spojena s populární kulturou. Respondenti ze všech zemí vypověděli, že se o ní dozvěděli díky televizi a internetu a že ji v minulosti někdy sami použili ve vlastních vyprávěních. Speciálním př́padem je právě Brazílie, kde postava často splývá s Comadre florzinha a Loira do Banheiro, i na ně však respondenti odkazují jako na „Brazilian Bloody Mary“." 1

O Krvavé Mary bylo také natočeno mnoho filmů především z hororového žánru. ${ }^{42}$ Její existencí se zabývají i různé seriály pro mládež (např. americký seriál Supernatural ${ }^{43} \mathrm{z}$ roku 2005).

\section{Kinderschreci z dětských knížek}

Pokud hovoř́me o fenoménu kinderschrecků jako součásti procesu remediace, ${ }^{44}$ nesmíme zapomenout na médium, které zde zatím nebylo dostatečně reflektováno. Tímto médiem je literatura. Ačkoli se může zdát, že knihy nezaujímají v životech dnešních dětí významnou roli, opak je pravdou. Čtení možná nepatř́ $\mathrm{k}$ všeobecně populárním dětským kratochvílím, každé malé dítě si však rádo vyslechne předčítání v podání dospělé osoby. A tyto př́iběhy pak mohou mít velký vliv na dětský vývoj a imaginaci. Důkazem může být například dětská knížka s názvem $K a$ -

\footnotetext{
40 IR, muž, 43 let, muzikant.

41 Dotazníky č. 1-5, Brazílie.

42 Např. snímek Bloody Mary (2006).

43 S01E05.

44 Tento jev byl poprvé popsán v publikaci Remediation: Understanding New Media autorů Bolter - Grusin (1999).
} 
rius og Baktus (Egner 1971). Jejím autorem je norský spisovatel Thorbjørn Egner, který skrze příběhy o dvou zubních skřítcích učí děti základním hygienickým návykům. Dětskými strašidly jsou v tomto př́padě Karius a Baktus, jejichž jména odkazují na zubní kazy a bakterie. Pokud si dítko nečistí zuby tak, jak má, zbytky jídla a sladkostí v ústech přilákají zubní skřítky, kteří svým životem v lidských zubech škodí jejich majiteli. Pravidelná ústní hygiena tato stvoření děsí.

Tato výchovná kniha byla také zpracována do podoby loutkových či animovaných filmů a reprodukována $\mathrm{v}$ podobě videí na různých internetových platformách (např. YouTube) ${ }^{45}$

Respondenti z Německa v rozhovorech uvedli, že se se skř́t ky setkávali především v tištěné podobě. Byla to kniha, kterou si četli sami, ve škole nebo jim ji četli rodiče. ${ }^{46}$ Jeden $\mathrm{z}$ dotazovaných tvrdí, že $\mathrm{v}$ dětském věku měl ze skř́ttků hrůzu a myslí na ně i dnes, když si ráno nestihne vyčistit zuby. ${ }^{47}$

Další zajímavou dětskou knihou je Struwreelpeter (Hoffmann 1967). Tato publikace je zajímavá př̀edevším tím, že v ní fyzicky nevystupuje postava kinderschrecka, nicméně měla (či stále má) na děti stejný efekt. Autorem knihy je lékař a psychiatr Heinrich Hoffmann, který př́běhy vytvořil pro své vlastní dítě. Struwerelpeter obsahuje velké množství krátkých poučných př́běhů o nerozumných a neposlušných dětech, dětech zanedbávajících hygienu atp. Každý prúběh je věnovaný jinému dětskému hříchu a provází ho jak velice názorné popisy důsledků neposlušnosti, tak děsivé ilustrace. $\mathrm{K}$ těm nejzmiňovanějším během mého výzkumu patřil právě Struwwelpeter, jehož zobrazení dodnes vyvolává v některých mých respondentech nepř́ijemné vzpomínky. ${ }^{48}$ Chlapec, který se nerad češe a stř́ihá nehty, je zde zobrazen jako zanedbaná postava s rozcuchanými kudrnatými vlásky a bizarně dlouhými nehty. Některé ilustrace Struwwelpetera dokonce evokují pocit, že si chlapec nehty rozdrásal obličej do krve. Ačkoli při bližším pohledu zjistíme, že stopy na obličeji zanedbané postavy jsou jen neučesané vlasy, jeden z dotazovaných z Německa přiznal, že se Struwwelpetera vždy bál, jelikož měl pocit, že je jediný, kdo jeho šrámy na obličeji opravdu vidí.

Kinderschreci jsou ne vždy děsivá nadpřirozená monstra s dlouhými drápy, ostrými zuby a pytlem na zlobivé děti. Čas od času může kinderschreck vystupovat jako celý narativ, jehož závěr je nějakým způsobem

45 Viz seznam videí dostupný z https://www.youtube.com/ playlist?list=PLL708Z91tWrtH__RetpOYuvDJ-KuD-ZI3.

46 Dotazníky č. 14-16, Německo.

$47 \mathrm{CN}$, muž, 26 let, učitel, Německo.

$48 \mathrm{CN}$, muž, 26 let, učitel, Německo. 
šokující, krvavý či jinak děsivý. Př́́kladem je pohádka, kterou jsem sama slýchala a z výzkumu dětských strašidel z roku 2016-2017 vím, že některým dětem hlavní hrdina této pohádky nedal spát. Jedná se o pohádku o malém Kryštůfkovi, který rád jedl sladké, a když jeho maminka pekla dort, schoval se v mixéru, aby mohl nenápadně ujídat. Maminka si dítěte v mixéru nevšimla a to způsobilo, že Kryštůfek, který rád jedl dorty, se sám stal dortem. Nerozumný Kryštůfek si ze svého osudu nic nedělal a pokračoval v ujídání dortu, ačkoli to znamenalo, že pojídá kousky sebe samého (Macourek 2011).

\section{Závěr}

Uvedený výběr kinderschrecků a jejich paralel představuje pouze rekognoskaci terénu v podobě menší sondy poukazující na nečekanou variabilitu, ale také vzájemnou podobnost strašidel např́ić podstatnou částí světa. Pravdou je, že téměř každé monstrum, každá záhadná postava, či dokonce každé zvíre má potenciál stát se kinderschreckem. Díky dynamice folkloru jako takového se každým dnem stávají dětskými strašidly nové a nové bytosti. Mohou jimi být filmové krakatice ${ }^{49}$ či jen obrázek Archeopteryxe z encyklopedie dinosaurů. ${ }^{50}$

At již schvalujeme užívání dětských strašidel v rámci výchovy, či patř́me $\mathrm{k}$ těm, jež tuto formu rezolutně odmítají, faktem je, že výskyt vyprávění o kinderschrecích se již vymyká naší kontrole. Především díky různým digitálním platformám je téměř nemožné najít v západním světě dítě, které by neznalo minimálně jedno z výše zmíněných strašidel. Každá tato platforma zároveň nabízí zcela jedinečný způsob nahlížení jednotlivých dětských strašidel a další šiřrení povědomí o nich. Příchod Webu 2.0 jakožto prostoru pro interaktivitu způsobil výrazné změny v lidské komunikaci. $Z$ internetu se rychle stalo médium zaměřené na shromaždování ohromného množství textu bez hlubší analýzy kontextu. Můžeme se setkat s celými vlákny v rámci diskusních fór, vtipnými historkami umístěnými na osobní blog, amatérskými (i studentskými, nebo dokonce profesionálními) videi, fotografiemi a obrázky, to vše věnované libovolnému strašidlu. Kromě rychlého šíření príběhů podporuje internet také syntézu jednotlivých narativů či jejich nosných motivů, díky níž je možné vysledovat výskyt prvků převzatých z internetu a jejich následné zakomponování do klasických folklorních příběhů. To je nejlépe vidět právě na př́íladu Bloody Mary, jenž v mnoha př́padech ${ }^{51}$ funguje jako jakýsi archetyp, pro-

49 VB, muž, 34 let, jaderný technik, Česká republika.

50 IP, žena, 54 let, fyzioterapeutka, Česká republika.

51 Všichni respondenti z Brazílie. 
střednictvím něhož lidé nahlížejí tradičnější folklorní bytosti jako Loira do Banheiro či Comadre florzinha.

Kromě internetu se o masové šíření přiběhů o dětských strašidlech zasazuje také kinematografie, která je přitahována především vizuálně atraktivními a zajímavými kinderschrecky. Hororový žánr nejčastěji pracuje s tajemnem, jež nabízejí éterické postavy jako La Llorona, či s vyloženě děsivým vzezřením Krampuse nebo Cucuye. Specifikem filmových kinderschrecků je však značná nekonzistentnost mezi narativy, ze kterých pochází inspirace ke ztvárnění dané postavy a jejím výsledným zpracováním, jež může být ovlivněno mnoha faktory, jako je reálný finanční rozpočet, umělecká vize apod.

Mohlo by se zdát, že modernizace společnosti vede $\mathrm{k}$ postupnému úpadku fenoménu kinderschrecků. Ústní transmise príběhů ustupuje masmédiím, dětská strašidla však procházejí evolucí stejně jako my a naše okolí. Jsou tady a jen tak nezmizí.

Duben 2020

\section{Anonymizovaný seznam zahraničních respondentů}

AE, muž, 23 let, Sýrie

AS, muž, 21 let, Itálie

AS, muž, 29 let, vývojář, Brazílie

AY, žena, 38 let, Brazílie

CN, muž, 26 let, učitel, Německo

CP, muž, 31 let, výzkumný pracovník, Velká Británie

DAMC, žena, 21 let, Mexiko

DL, muž, 24 let, Portugalsko

DO, muž, 35 let, elektrikář, Kolumbie

DY, žena, 33 let, skladnice, Velká Británie

FR, žena, 26 let, Francie

GM, muž, 39 let, producent, Portugalsko

GP, žena, 28 let, pracovnice zákaznického servisu, Itálie

GT, muž, 26 let, fotograf, Indonésie

IP, žena, 54 let, fyzioterapeutka, Česká republika

IR, muž, 43 let, muzikant, Mexiko

JPK, muž, 30 let, Nizozemsko

MC, muž, 28 let, softwarový inženýr, Brazílie

MG, muž, 28 let, projektový manažer, Německo

OC, muž, 26 let, Turecko 
OE, žena, 27 let, scénáristka, Turecko

PHSM, muž, 29 let, hudebník, Brazílie

RB, muž, 23 let, Francie

RH, muž, 29 let, softwarový manažer, Německo

RH, žena, 36 let, Itálie

SZ, žena, 29 let, ilustrátorka, Portugalsko

TK, muž, 21 let, Portugalsko

UT, muž, 26 let, student, Pákistán

YVSS, muž, 26 let, překladatel, Brazílie

\section{Literatura}

Bascom, William R. 1954. Four Functions of Folklore. Fournal of American Folklore 67: 333-349.

Bittnerová, Dana - Janeček, Petr (ed.). 2011. Folklor atomového věku: kolektivnè sdílené proky expresioní kultury v soudobé české společnosti. Praha: Národní muzeum.

Bolter, David J. - Grusin, Richard. 1999. Remediation: understanding new media. Cambridge: MIT Press.

Cypess, S. Messinger. 1991. La Malinche in Mexican Literature: From History to Myth. Austin: University of Texas Press.

De Laguna, Frederica - McClellan, Catherine. 1981. Handbook of North American Indians. Ed. June Helm. Washington, D.C.: Smithsonian.

Egner, Thorbjørn. 1971. Karius og Baktus. Oslo: Cappelen.

Hoffmann, Heinrich. 1967. Der Struwwelpeter: lustre Geschichten und drollige Bilder. Aufl. Berlin: Kinderbuchverlag.

Chawla, Janet. 1994. Child-bearing and culture: women centered revisioning of the traditional midwife: the dai as a ritual practitioner. Indian Social Institute.

Janeček, Petr. 2015. Krvavá Máry a jiné strašlivé historky. Praha: Plot.

Kracík, Pavel. 2018. Peckovský Kumraus. Lokální varovná bytost jako doklad česko-nèmecké jazykové hranice. Studia Ethnologica Pragensia. Univerzita Karlova, Filozofická fakulta, 75-91.

Macourek, Miloš. 2011. Pohádky. 2. vyd. Praha: Mladá fronta.

Pospíšilová, Jana. 2005. Kultura dětí. In: Tyllner, Lubomír - Uherek, Zdeněk (eds.): Kultura - společnost - tradice I.: Soubor statí z etnologie, folkloristiky a sociokulturní antropologie. 1. vyd. Praha: Etnologický ústav AV ČR.

Ridenour, Al. 2016. The Krampus and the Old, Dark Christmas: Roots and Rebirth of the Folkloric Devil. Washington: Feral House.

Smith, W. Ramsay. 1930. Aborigine myths and legends. London: George G. Harrap. 
Thompson, Stith. 1989. Motif-index offolk-literature: a classification of narrative elements in folktales, ballads, myths, fables, medieval romances, exempla, fabliaux, jest-books, and local legends. IN: Indiana University Press.

Thorpe, Benjamin. 1852. Northern mythology: comprising the principal popular traditions and superstitions of Scandinavia, North Germany, and the Netherlands. Londýn: Lumey.

Tomsa, František Jan. 1794. Nesstáastné přjhody k wýstraze nezkussené mládeži, w pronikawých přjkladech, a obrázcých, kteřj ge wyswětlugj. Praha: Jan Karas.

Váňa, Zdeněk. 1990. Svět slovanských bohů a démonů. Praha: Panorama. Williams, Rhys T. 1965. The Dusun: A North Borneo society. New York: Holt, Rinehart and Winston.

\section{Webové zdroje}

Empousa - Lamia. 2000. [online]. [2019-10-27]. Dostupné z: https://www. theoi.com/Phasma/Empousai.html.

Erben, Karel Jaromír. 2011. Prostonárodní české písně a říkadla [online]. V MKP 1. vyd. Praha: Městská knihovna v Praze. [2019-12-04]. Dostupné z: http://web2.mlp.cz/koweb/00/03/64/89/81/prostonarodni_ceske_pisne_a_rikadla.pdf.

Karius og Baktus [seznam videí]. (n.d.). [2020-02-10]. Dostupné z: https://www.youtube.com/playlist?list=PLL708Z91tWrtH_RetpOYuvDJ-KuD-ZI3.

Norder, Dan. 1999; 2003. The Face in the Mirror: Looking at Bloody Mary, Mary Worth and Other Variants of a Modern Legend [online]. [2019-0902]. Dostupné z: https://web.archive.org/web/20070430222448/ http://www.mythologyweb.com/bloodymary.html.

Plascencia, David Ramírez. 2017. The Role of the Internet in the Endurance of "La Llorona" as a Liminal Archetypal Monster in Modern Latin American Society [online]. [2019-09-06]. Dostupné z: https://www.academia. edu/33261119/The_Role_of_the_Internet_in_the_Endurance_of_La_ Llorona_as_a_Liminal_Archetypal_Monster_in_Modern_Latin_American_Society.

Sugiyama, Michelle Scalise - Sugiyama, Lawrence S. 2011. Once the Child is Lost He Dies: Monster Stories vis-a-vis the Problem of Errant Children. In: Creating Consilience Integrating the Sciences and the Humanities [online]. [2020-02-18]. Dostupné z: http://www.oxfordscholarship. com/view/10.1093/acprof:oso/9780199794393.001.0001/acprof9780199794393-chapter-20. 


\section{Filmy}

The Nightmare Before Christmas [film]. Režie Henry Selick. USA, 1993.

Cucuy: The Boogeyman [film]. Režie Peter Sullivan. USA, 2018.

Dalskabáty, hř́šná ves aneb Zapomenutý čert [film]. Režie Jiří Bělka, ČSR, 1976.

S čerty nejsou žerty [film]. Režie Hynek Bočan, ČSR, 1985.

The Curse of La Llorona [film]. Režie Michael Chaves, USA, 2019.

Bloody Mary [film]. Režie Richard Valentine, USA, 2006.

\section{Seriály}

Greenwald, Todd J. Wizards of Waverly Place [seriál], USA, 2007.

Whedon, Joss. Buffy the Vampire Slayer [seriál], USA, 1997.

Carpenter, Stephen. Grimm [seriál], USA, 2011.

Kripke, Eric. Supernatural [seriál], USA, 2005. 